上昇及び．．P．R．の陽轉を見た。

(2) 電圖に於て感作 10 回目頃より $\mathrm{T}$ の低下扵る

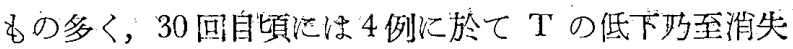
を認めた：併しST の變化を來したものは1例もなかつ た。

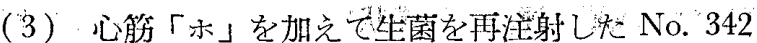
の心筋に形質細胞を主とする間質性心筋炎の他に，內膜

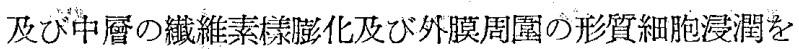
伴万結篩性動㭽周堛炎を左右心室の心外膜下に認めた。

（4）心筋「ホ」を加えない例には極めて輕微な間質
性心筋炎しか認められない。

（5）罢丸には膿瘍を形成し之を結締組織が園んでい て理想的とは言えないが focus 形成している，睪丸白 膜の血管周園にも形筫細胞性反膲を認める。

之を要するに本賔驗に於て心筋「ホ」により睪丸を focus とする溶速菌の抗原抗體反㷳が心筋に於て選擇的 に行われ，從つて臟器特基的に結管性動脈周園炎を伴了 間質性心能炎を作成することに成功した。

本諭交要旨は炤和 24 年 4 月日本循環器學會第 13 回總會に拎て等表 乙市.

From the Third Medical Clinic of Kyoto University (Director: Professor M. Maekawa, M. D.)

\title{
Studies on the Experimental Carditis by Streptococci Viridans I
}

$\mathrm{Br}$

Hiromi Hotta

(Received for Publication, Mar. 2, 1951)

\section{綠色連鎻狀球菌に依る實驗的心炎の研究 （第 1 報）}

\author{
醫學士堀 田 博 美

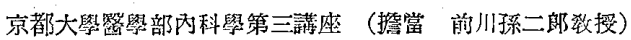

Mackawa expresses the opinion that in the allergic diseases phosphatide from any organ or tissue makes the antigen combine with that organ or tissue. Therefore, I expected that when rabbits were sensitized by the mixture of streptococci viridans and rabbitheart-muscle or men-heart-endcardium-phosphatide, the cocci would adhere to the heart to produce an allergic carditis. On the first experiment I sensitized rabbits by the intertesticular injection of the streptococci viridans with rabbit-hert-muscle-phosphatide. Clinically body weight, body temperature, blood pressure, blood picture and urines were not so changed,

\section{第 1 章：緒論及び實驗材料}

心臟疾患を起す原因としてリウマチが重要な役割を演 ずる事は古くより Rüille ${ }^{1)}$, Riegel ${ }^{2}$ ), Krehl ${ }^{3)}$, Romberg ${ }^{4)}$ 等に依り記述せられて居るが，1904 年 Aschoffi), 1906 年

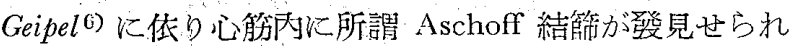
之をリウマチの病理的特徵としてから，續いて Coombs 7)

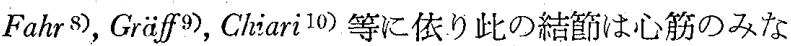
らず其の他血管，關節，扇桃腺，全身の彭粗性結締織に も認められ，リウマチの本態に闇する咑究性枚擧に睱が 無いが其の原无に蔼しては種々の說が立てられ未だ決定 されて居ない。

Aschoff门)に依り提唱せられた特旅病原哃說は，Gräf は急性リウマチを組織學的厄特殊な反應を著起する Rheumatismus infectiosus speci-ficus なりと提言し，特 but electrocardiogram showed myocardial damages CPR-reaction by Araki showed positive and complement in the blood decreased.

After killing the rabbits, I investigated histo logically all organs of them, especially heart. I found more remarkable allergic interstitial myocarditis at the experimental animals than the controls. At one of the experimental rabbits I found a large basophilic monnuclear cell in the perivascular plasma cells. The purulence and incease of the connective tissure were recognized in the testicles of all animals.

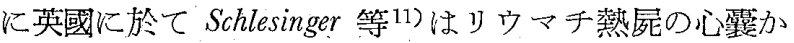

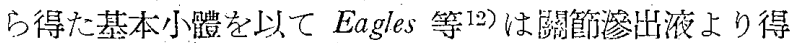
た夫れを以て凝集反應を行い，Brokman 等13) はリウマチ 熱小兒肚臟より,得た濾液を以て袺體結合反㷳を行いリウ マチ熱の病原睛を一種の Virus となし，之に對し最近 G.ordon 等14) いて動物實驗を施行し斯くして得た病變はリウマチの組 織像に似な㱍化として virus 說を支持して居る.

Poncet 15) に依るリウマチの結核說以來，Schwarz \& Bieling ${ }^{16)}$ は結核アレルギーの賽驗的研究に於てAschoff 結篩類似の結篩の發皆を報告し, Altmann \& Gerzner ${ }^{17)}$ はリウマチに於计る扁桃腺の役割に注目し屚桃腺周園組 織に結核菌を注射し同樟な結果汇到達した．結核屍心欌 にAscooff 結篩を思わす如き像を認めたのは Brockhausen 
18)，馬杉㸚授 19) であり更に同敎授 20)はリウマチ結節と 結核結節々の間に種々の移行像があり而も之は血行性結 核症に牛數以上認められる事より，リウマチ熱が血行性 結核のアレルギーの一つの現われとする. 然し動物實驗 に於ては未だ定型的の Achoff 結節を作り得て居ない.

アレルギー誢は vonPirquet 21$)$ がアレルギーを組織の反 應能力の變化と云う概念に表現してから，Weintraud ${ }^{22}$ ) リウマ熱と血清病とが躁㕅的に類似する事より，リウ マチは扁桃腺感染に依る細菌產物に起因する過敢反㷳な りと主張し，一方 Klinge 23) は家東を馬血清で感作し其

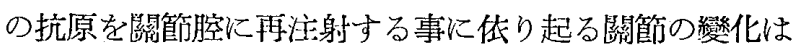
リウマチ尼に見られる 1) リウマチ早期浸潤期，2）肉 芽腫形成期， (3)? 洀痕形成期の敦れかに堨与る組織像に 一致する事よりアレルギー說を强調して居る. 最近米國 に於ても此の種の研究が盛に行われる樣になり，Rich及 び Gregory 24) 膜，心外膜等に Aschoff 結師に似た像を得たと報告し， Ehrlich ${ }^{2 i), ~ M o r e ~}{ }^{26)}$ 等は異種蛋白を用いて結笁性重胍周

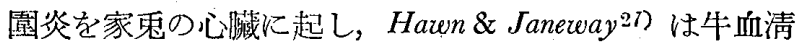
アルブミン，rグロブリンを大量家象に注射し心筋炎, 亚炎，血管炎或いは關節炎を作り，且つ抗原が血中に份

存在する時期に急性變化が起り，抗原消失，抗體出現と 同時に治離が起ると言う。

リウマチの球菌說に閶しては古來幾多の研究者に依り 提案せられ，リウマチ患者の血液，扇桃腺，關節，尿，

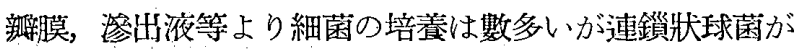

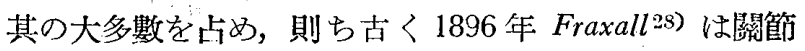
より細菌を證明したと報告, 头いで Westphal, Wassermann \& Malkoff ${ }^{29)}$ は血液, 腦，心臟辦膜より連鎻狀球菌 の培着に成功し，之を家鬼に注射して其の大多數に關篩 炎を若起せしめた: 次に Poynton \& Paine30) は急性リウ マチ熱患者血液, 扇桃腺, 心囊液, 竍膜より双球菌を培 養し，該囷の家鬼靜胍內注射心依り關節炎，心內膜炎， 心外膜炎，心朌變性を認女之に diplococcus rheumaticus なる名䊈を與えた. 續いて 1903 年 Beaton \& Walker ${ }^{31),}$ 1909 年 Bracht \& Wächter ${ }^{32}$ ) も同樣に連鎻狀球菌の培飬 飞成功, Griuseppe ${ }^{33)}$ 《舞踏病患者血液上り證明, Coombs 等34)もりウマチ患者心藏瓣膜より得た逨鎻狀球菌は動物 實驗厄依り心炎, 關節炎を起し佮其の際心筋内に Aschoff 結節類似の像を認めたと報告，Rosenow ${ }^{35)}$ ) 同樣に連鏆 狀球菌の培養に成功，更に Clawson ${ }^{36)}$ は可成り高率に 血液，關節，心霓液等より培養に依り得られる緑色連鎻 狀球菌は之を家鬼に注射し其の $37 \%$ 亿心內膜炎を㤰起 せしめ得る事より，リウマチ熱は本菌に起因するものと する．然るに其の後 Small37) はリウマチ熱患者血液より の連鎻狀球菌 $(r$ 型)の血清學的及び實驗的研究上り，之 をStreptococcus cardioarthriticus と命名しリウマチの 依つて起る本態となし，Birkhaug ${ }^{38)}$ \& toxigenic Nonmethemoglobulin-forming Streptococci の毒素に依る 皮慮反應はリウマチ患者及びリウマチ既往歷有る者に高
率に現われ，且つ實驗的に罪節炎，心炎等を惹起する事 を記載し，之に反し Cecil, Nicho!ls \& Stainsbyت9) は \& 型を重要悓して居る. 次いて Forkner ${ }^{40)}$, Lichtentritt ${ }^{41)}$, Lichtman 等42) 当連鎻狀球菌を說明して居るが，之に對し Nye \& Seegel ${ }^{4 ミ}$ はリウマ于熱患者 25 例中全例共姐液培 養陰性の成績を述べ，連鎻狀球菌說に反對的立場に立脚 する. 然し乍ら Suranyi \& Forrō ${ }^{44)}$ はアドレナりシ並び に硫黄劑注射に依れぱ，血液培峑成績はより高率に陽性 化守ると言う。

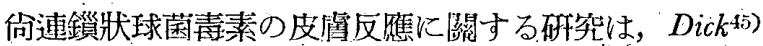
以來 Birkhaug ${ }^{38)}$ 4(), Kaiser ${ }^{47)}$, Irvine-Jones ${ }^{48)}$ 等に依り行 われリウマチ既往歷を有する患者にはリウマチ熱患者 より得た逨鎻狀球菌毒素に對し，皮留反㷳は 24 時間で 高率に現出する事が述べられて居る.上記は凡て非溶血 性連鎻狀球菌を主體とした㸴究であるに反し Coburn \& Pauli ${ }^{49)}$, Todd 50) 等はリウマチ熱患者よりの溶血性連鎻 狀球菌は非リウマチ患者よりの夫れに比し erythrotoxin 及び hemolysin を多く作るもので，患者血清中には antistreptolysin-C 價の上年する事より連鑟狀球菌須を 肯芫し，Rant $z$ 等 51 1) $\beta$ 型 $\mathrm{A}$ 群菌の上氣道感染患者に はリウマチ熱を見るに反し，A 群でない、浴連菌の感染患 者にはリウマチ熱患者を見出さず，且つ種々のA 群菌

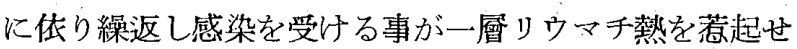
しめ得ると言5. 最近 Criep \& Mayer ${ }^{52)}$ は $\beta$ 型溶連 菌毒素を用いて䁈驗的にリウマチ性心炎，結鹤性動胍周 图炎を作り，Harris 53) は A 群溶連菌を超鼓心に低り R 分劃(不溶性殘渣)， CP 分劃(原形質粒子)， S 分劃(蛋白 軆溶液）に分ら之を用いて患者血淸との間に袢體結合反 㷳を行い，GP 及び $\mathrm{S}$ 分劃に對する抗體は健康者にも存 するが低瑻なるに比し，猖紅熱，リウマチ熱患者には高 い事を述べて連鎻狀球菌說の根據とする.

連鎻狀球菌說にアレルギーの概念を溥入したのは $M a$ ckenzie \& Hanger ${ }^{54)}$, Dochez \& Stevens ${ }^{55)}$, Zinsser \& Grinnell ${ }^{56)}$ 友び Swift 一派57)58)59)60)61) であるが，Swift は初め $\gamma$ 型或いは $\boldsymbol{\alpha}$ 型を以て實驗を行つて居たが最近 は $\beta$ 型を擧げて居る. 之より先 Schloss \& Foster ${ }^{62)}$ は連 鎻状球菌の反覆注射に依り關篩滑液膜の肥厚を有する慢

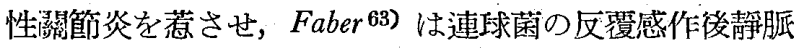
內注射に依り例外なく關節炎が起り，此の糸節炎と人り ウマチ熱再發との間に酷似性の有る事を報告，一方馬杉 及び不楅 (4) は連鎻狀球菌を少量より初めて堽星的に反覆 注射して心內膜炎を起し, Murphy \& Swift心) は連球菌 の皮內注射が靜胍內注射上り感作度の高い事及び或る種 の菌を以て感作させる場合, 他種の菌に對して皮膚反應 が同種の物より强度な事より， $\beta$ 型 $\mathrm{A}$ 群溶連菌の種々 の株を長期間反覆家香に皮队注射し，心筋冈にリウマチ に酷似した Aschoff 巨態細胞を有する結笁を作り，之を 人リウマチ心の結節と比較呼究し $\beta$ 型溶連菌 (A 群)を リウマチの原因として決定的に論じて居る.

之とは別に病巢感染の概念がある.1910年英醫Wil. 


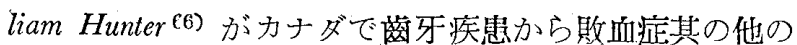
全身疾患を起寸事が多いと講演するに及び，之が醫學界 の注目を浴び，Billings 67) は苳牙疾患のみならず尾桃腺，

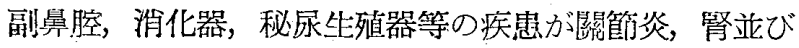
に心臟疾患等を若起し得ると詳述し，續いて Rosenow ${ }^{68)}$ ， Haden ${ }^{699}$, Bernhard ${ }^{70)}$ 等に依る細菌の藏器選擇性の實驗 的研究，炎にアレルギーの概念を挿大したGerlach ${ }^{71)}$, Siegmund ${ }^{72)}$, Rössle ${ }^{75)}$, Gutzeit \& Parade ${ }^{74)}$ 等飞依る論述

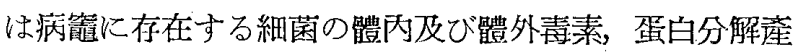
物等が抗原として淋巴，血液を介してリウマチ性心炎を 起すと言5. 實驗的には Cecil \& Angevine ${ }^{75)}$ は家東の茼

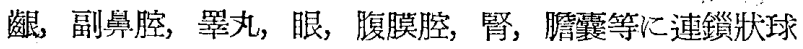

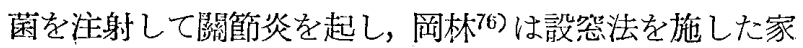
串の副鼻腔內に溶連菌を反覆注射して其の多數例に漺漫 性絲期體臂炎を，其の數例に於て心筋炎，旂状心內膜炎 を認め此等の所見より病筐感染說を，强調する．最近堂 野前，湛邊7门は Rössle ${ }^{78)}$ の方法に依り $8 \%$ アロイロナ

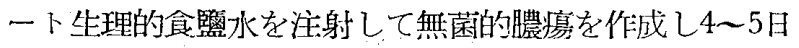
後溶連菌の一定量を反覆注射し状踈心內膜炎，閒質性心 筋炎を認めて居る。

リウマチ性心炎之關係の深いものに Libman \& Celler 79), Schottmüller ${ }^{80)}$ 等に依り記載され其の 90〜95\%は綠 色連鎖牀球菌に起因する亞急性細菌性心內膜炎なる疾患

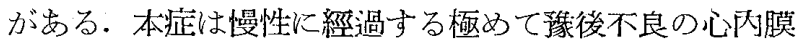
炎て，弛張㓐，瓔血，脾腫，血尿等を伴う疾患にして， Bierringsi), Fulton \& Levines:), Davis ${ }^{83)}$ 等は其の過牛 數にリウマチの敗往症を有すると云い, 組織學的にも Saphire 等84) は特徵的な心內膜のVegetation, 潰演のみ ならず心筋炎，周管性血管炎，Aschoff 結節等のリウマ チ型を記載し Clawson \& Bell: 8i) 女此の雨者は同一の 過程より發生し，互急性細菌性心內膜炎は感染性血检の 出來る時期にしてリウマチ型は症狀緩慢なる瓣膜炎なり と言う.VonGlahn \& Pappenheimer ${ }^{86)}$ は再三りウマチ性 心內膜炎を繰返与心臟のVegetationに細菌感染学起し

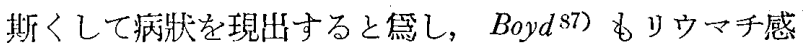
染は紽連菌の感染を容易ならしめ, 組織學的にリウマチ 型及び敗烅型を同一心臟腹見せられる所似と鹪して居 る. 然るに最近前川㸚授 ${ }^{99}$ は本疾患の病因河き後述の アレルギー历び冤度の理論より、アネルギーではなくア

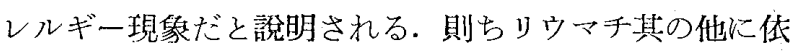
り障碍せられた心內膜から遊離した組成物質（多分は心 內膜ホスフアテイード）が血流に大り，流血中の細菌と

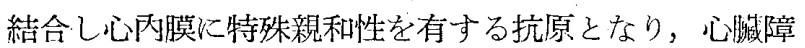
碍を㴔起寸ると言われる。

以上の如く細茼或いは買種蛋白體を朋いてアレルギー 性病變孝組織に起さしめた貫驗は數多いが，特定の臟器

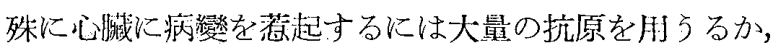
或は Auer ${ }^{89)}$ の實驗以來局部的の操作に依る抗原富化 の處置が加党られ衫ぱ仲々困難なるのである.從つて Vaubel ${ }^{90)}$ の寒冷剌钱，馬杉㸚授 ${ }^{91)}$ のnephrotoxin, $K a$ - iserling ${ }^{92)}$ の血管神經排除衍，Rintelen ${ }^{93)}$ の血管結禁， Kinsella \& Muether ${ }^{94)}$ の小刀に依る心臟瓣膜破碎，其の 他ホルモン劑の併用，抗原の局所への再注射等が考案さ れたが，大西酒) は豚及び牛血清感作家鬼の耳翼動胍を再 注射時强く厴迫しアレルギー性末枮血管炎を起す事に成 功し，且つ甲贸腺ホルモン，腦下垂體前葉ホルモン，ア ドレナリン，寒冷溫熱刺㦸に依り病變の墦强するのを認 め，村區96) は馬血清で頻回感作した家鬼を寒冷に曝し，

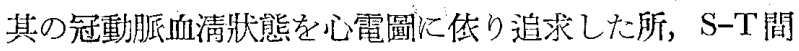
隔の低下， $\mathrm{T}$ 波高の縮少を認め，脫感作に依り其の程度 の減弱するのを見た。

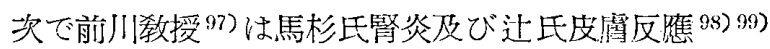
100)の批刵からアレルギー性疾患に於ける臟器特殊性は, 抗原の特定臟器に對する親和性に依るものにして，然ら ぱ用藏器に親和性を有する物質に依り抗原を該膊器に拘着 せしめ得れぱ，該臟器にアレルギー性病變を起し得るの ではないかとされ，大阿101)央び鹰津，野田 102)103)は心 筋に親和性を有するヂキタリスと牛血清との混合物を抗 原として血管周園炎性心筋炎を，昇承加牛血埨を用いて 實驗的高血澵症を起すに成功した。

そこで前川㸚授 ${ }^{104)}$ は斯る物筫を娟內物質に求め九事

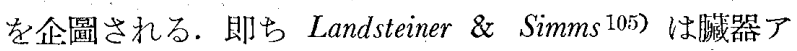
ルコールエキスに異種蛋当體を附加する事に依り抗原性 の付與せられる事を發見し，Lehmann-Facius 106) は癌腫 より抽出せるホスファティード分劃を抗原として癌患者 血淸のオイグロブリン分劃との絮狀反隹に依る血淸學的 癌腫診㽧法を發表し，ここに於て前川敉授は荒太107)に 依啒して心筋ホスファティードと心悈病患者血清オイグ ロブリン分劃と反應せしめ，心能障碍の約 $86 \%$ を診斷 し得る事に成功した。 そこで野田 ${ }^{108}$ ( は心筋水スファテ ィード加牛血清を抗原として家忽を感作再注射して，心 儎に選擇的且つ著明の血管周園炎性間質性心筋炎を作り 得た．而して前川㸚授 ${ }^{109)}$ ば此の場合藏器ホスファティ 一ドは抗原である血淸を特定臟器に拘着せしめる親和族 の作用を呈するものであるばかりでなく，それに對する 特異性抗體を決定する決定族となり，ヂギタリ大加血清 が心筋に特異的のアレルギ一性炎症を示すのは，單に抗 原を心等に親和的とするばかりでなく，其の際用いられ た異種蛋白が心臟ホスファティードと結合するに十分な

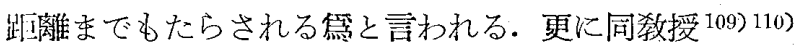
111) は免度とアレルギ一を原国的に區別され，嵬疫は抗 體の特異性を決定する抗原の決定群が，此の抗體力製作 せられる生體の個有物質とは無關係である㘯合で，從つ て其の際の抗原抗體反應は，本質的に生體に反應する物 質を，生體に反應しない物質に轉化する事であり，之に 反してテレルギーは抗體の特異性を決定する抗原の決定 群が，其の抗體が製作せられる䟚體の固有物質である場 合で，從つて其の際の抗原抗體反應は，本質的に生體に 反鷹しない物質を比體に反應する物質に轉化する事であ り，歲器ホスファティードは琒體內に於けるハプテンの 
作用を示するのとされた。

最近アメリカに於てもSchultz \& Rose ${ }^{112)}$ は溶血性連

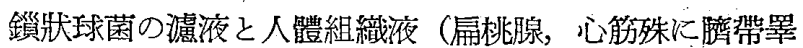
丸結締織）或いは人血清アルブミンとの湿合物を以て, 甘日鼠沦りウマチ型心炎を作り，又 Carelti 113) は心臟， 結締織，骨骼筋のエムルジォンと $\beta$ 型溶連菌（A 群）の 死菌との混合物を抗原とし大黑鼠にりウマチ型心筋炎を 作り，血清學的にコロジョン粒子を加光た前記エムルジ オンと動物血清との間に架狀反應を行い其の强度と組織

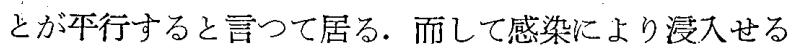
細菌と體內に遊離して居る組織成分とが結合し，之が抗

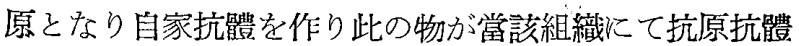
反應を呈すると言い組織成分をハプテンと看做して居る が，組織エムルジオンは蛋白體を含む故ハプテンとは言 い難く勿論冏器ホスファティードとは異つた物である.

此處に於て著者は獩器ホスファティードの特殊親和力 に注目し，心筋及び心內膜ホスファティードを綠色連鎻 狀球菌と混和して家鬼を感作再注射すれぱ，“綠連菌は心 臟に拘責せられて，此處に容易にアレルギー性心炎を起 し得ると想定し，趆いてはりウマチの連鑟狀球菌說をる 檢討せんとして，先ず第一炔賽驗に於て心筋ホスファテ ィードを，第二次實驗に於て心冈膜ホスファティードを 綠連菌に附加して實驗を行い，之を臨床的並に病理組織 學的に詳しく追求したので其の成績を報告する。

\section{實 驗 材 料}

1）綠色連鑽狀球菌：第一次實驗に於ては大阪大學微 生物研究所藤野致授の御厚意に依り受領した扇株にして 第二次實驗では京都大學醫學部內科學第三檴座入院患者 (病名：亞急性細菌性心內膜炎)の血液培養に依り得た野 上株を使用した. 本菌の山羊血液葡萄糖加寒天斜面 18 20 時間培羬の新鮮なる菌苔を用に供した。

2）心筋及び心內膜ホスファティード抽出法: 荒木 107) の行つた方法汇依り家需心筋，人心內膜組織上り抽出し た。剖檢により得た家鬼心筋或いは人心內膜（可及的新 鮮なる物を可とするる己むを得なければ 10\%ホルマリ ン水中に固定したもの）を良く水洗し，可改的血液或い はホルマリンを去り，濾紙にて全く水分を嗄收し；細屑 後乳鉢中で良くすりつぶし畭燥科量し夫々を所定の瓶に 入れ，5管量の無水酒精を加兄密栓封臘し室溫心一週間 以上放置する. 次酒精を滤過し水沿上で蒸發乾燥させ 殘查をベンジールに溶解 (酒精量の約 $1 / 2 〜 2 / 3$ 量)，一旦 加熱後冷却滤過する。ベンゾールは再び水溶上で蒸發乾 燥させ，此の殘查にアセトンを加兄，一度加盜し冷却後 アセトン可溶部分を取去る. 斯くして得た殘查を石油エ ーテルに溶解濾過し石油エーテル蒸發後殘查を科量し無 水酒精液として水室に保存し，使用に際しては酒精を蒸 發させ減菌生理的食鹽水浮游液として用弓る。

\section{第 2 章 第一次實驗 \\ 第 1 節 實驗方法}

嘪驗動物は體重 $2.0 \mathrm{~kg}$. 前後の雄性家鬼 8 匹を用い,
內 5 匹 (No. 369，370，371，372，373) を本賽驗炕，3匹 （No. 350，367，367） を對照實驗に夫及使用し，全經過中 糠，青草等を以て鸰養し特に榮盖牀態注意した。

感作は Table 1 亿示守如く各家鬼共（但しNo. 350 は 靜脈內注射の夕) 30 回睪丸內儿，最初 20 回は隔日，後 10 回以每日行い，綠色連鎻狀球菌は前記。扇株の山羊血液葡 萄糖加寒天斜面 18２0 時間垤養の新鮮なるもの，最初 10 回は $1 / 30$ 斜面，次の 10 回は $1 / 20$ 斜面，最後の 10 回は

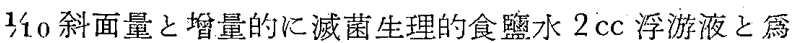
し, 反覆左右交互睪丸內飞注射す。偷其の際心筋木ス アティード加綠漸菌の睪丸內注射の場合は，心筋ホスフ

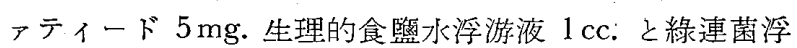
游液 1 cc. とを混合，全量 2 cc. と覅したる後，䁔卵器 $\left(37.0^{\circ} \mathrm{C}\right)$ 中にて約 1 時間放置也るものを，心筋ホスファ ティード静脈內注射の場合は $10 \mathrm{mg}$. 生理的食覧水 $2 \mathrm{cc}$. 浮游液としたものを使用に供した。前記諸操作は總て無 菌的以行5.

30 回の感作終了後9 日を經て，1２０斜面の菌量の心筋 ホスフ、アティード加（但し對照實驗では心筋ホスファテ

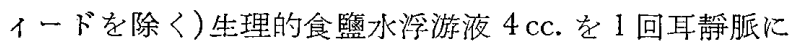

TABLF 1

\begin{tabular}{|c|c|c|c|c|c|c|c|}
\hline No. & & \multicolumn{3}{|c|}{ Sensitization } & \multicolumn{3}{|c|}{ Reinjection } \\
\hline 350 & \multirow{3}{*}{ 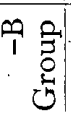 } & & \multirow{2}{*}{\multicolumn{3}{|c|}{ St.v. (i.v.) }} \\
\hline 367 & & \multirow{2}{*}{\multicolumn{3}{|c|}{$\begin{array}{l}\text { St.v. (i.t.) } \\
\quad 30 \text { times }\end{array}$}} & \multirow{2}{*}{\multicolumn{3}{|c|}{ once }} \\
\hline 368 & & & & & & & \\
\hline$\frac{369}{370}$ & \multirow{4}{*}{ 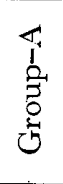 } & \multicolumn{3}{|c|}{$\begin{array}{l}\text { St.v.+Ph. }(5 \mathrm{mg}) \\
\text { (i.t.) } 30 \text { times }\end{array}$} & \multicolumn{3}{|c|}{ St.v. + Ph. $(10 \mathrm{mg})$} \\
\hline 371 & & \multirow{3}{*}{\multicolumn{3}{|c|}{$\begin{array}{l}\text { St.v. (i.t.) } \\
\text { Ph. }(10 \mathrm{mg}) \text { (i.v.) } \\
30 \text { times }\end{array}$}} & \multicolumn{3}{|c|}{ (i.v.) } \\
\hline 372 & & & & & \multirow{2}{*}{\multicolumn{3}{|c|}{ once }} \\
\hline 373 & & & & & & & \\
\hline \multicolumn{2}{|c|}{ Remark } & \multicolumn{6}{|c|}{$\begin{array}{l}\text { St.v. (Streptococci viridans), } \\
\text { Ph. (rabbit-heart-muscle-phosphatide), } \\
\text { i.t. (intratesticular), i.v. (intra-venous) }\end{array}$} \\
\hline \multicolumn{8}{|c|}{ TABLIE 2 Bodyweight $(\mathrm{kg})$} \\
\hline Nc & & $\begin{array}{c}\text { Before } \\
\text { Ex- } \\
\text { Periment }\end{array}$ & $\begin{array}{l}\text { Sensiti- } \\
\text { zation } \\
\text { l0times }\end{array}$ & $\begin{array}{l}\text { Sen } \\
\text { zat } \\
20 \mathrm{t}\end{array}$ & & $\begin{array}{l}\text { After } \\
\text { Sensiti- } \\
\text { zation }\end{array}$ & $\begin{array}{l}\text { After } \\
\text { Re- } \\
\text { injection }\end{array}$ \\
\hline 35 & & 1.95 & & & & & 1.95 \\
\hline 36 & & 1.89 & 1.85 & & & 2.00 & 2.05 \\
\hline 36 & & 2.75 & 2.70 & & & 2.75 & 2.65 \\
\hline 36 & & 2.30 & 2.25 & & & 2.40 & 2.35 \\
\hline 37 & & 1.75 & 1.85 & & & 1.85 & 1.80 \\
\hline & & 1.85 & 2.10 & & & 2.05 & 2.05 \\
\hline 37 & & 1.65 & 1.70 & & & 1.70 & 1.80 \\
\hline 37 & & 2.05 & 2.10 & & & 2:15 & 2.25 \\
\hline
\end{tabular}

TABLE 3 Body temperature $\left({ }^{\circ} \mathrm{C}\right)$

\begin{tabular}{c|c|c|c|c|c}
\hline \hline No. & $\begin{array}{c}\text { Before } \\
\text { Ex- } \\
\text { periment }\end{array}$ & $\begin{array}{c}\text { Sensiti- } \\
\text { zation } \\
\text { 10times }\end{array}$ & $\begin{array}{c}\text { Sensiti- } \\
\text { zation } \\
\text { 20times }\end{array}$ & $\begin{array}{c}\text { After } \\
\text { Sensiti- } \\
\text { zation }\end{array}$ & $\begin{array}{c}\text { After } \\
\text { Re- } \\
\text { injection }\end{array}$ \\
\hline 350 & 38.3 & & & & 39.0 \\
367 & 37.9 & 38.3 & 38.4 & 38.7 & 39.7 \\
368 & 38.4 & 33.7 & 38.6 & 38.2 & 39.5 \\
\hline 369 & 38.3 & 38.6 & 38.7 & 38.5 & 39.7 \\
370 & 38.0 & 39.6 & 38.7 & 38.3 & 40.1 \\
371 & 37.6 & 39.0 & 38.9 & 39.0 & 39.8 \\
372 & 38.1 & 39.4 & 38.5 & 39.1 & 39.6 \\
373 & 38.2 & 38.9 & 38.5 & 39.0 & 39.8 \\
\hline
\end{tabular}


再注射する。

再注射後 3 日，9 日後動物を失血致死させ，直らに心 肺，肝，脾，㛑，副腎，睪丸等を摘出し，之を $10 \%$ ホル マリン水で固定し，ッェロイギン包埋切片とし，へマト キシリン・エオジン重染色法, Van Gieson 氏染色法等 を行つて鏡檢した。

全動物に就て實驗前及び全經過中を通じて體重, 體溫 血壓，尿，血液像，心電圖，補體量欢び心筋ホスファテ イード反應107) (G.P.R.)の檢查を觀案した。

血厭は川口氏 ${ }^{114)}$ の非觀血的方法に依り耳款中心動脈 に於て測定し耳殼血管運動神經の影響を除く雼 Feldburg 115) に從い Nn, auriculares dorsales et ventrales $の$ 切 聯及び上頸交感神經節の摘出を行い，測定に虽つては耳 款中心動脈の一定點で行う樣注意し，數回测定し其の本 均值を採用した。

檢尿はネラトン氏カテーテルで導尿した尿につき，蛋
白, ウロビリン，ウロビリノーダン，糖，沈渣等に就き

檢查した。

血液は家克耳翼の末梢血を用い，赤血球數，血色素量 白血球數，血小板數，白血球百分率，網狀赤血球等に就 き檢查した。

補體量测定及び心筇ホスファティード反應施行に際し

Table 4 Blood Pressure (mmHg)

\begin{tabular}{|c|c|c|c|c|c|}
\hline No- & $\begin{array}{l}\text { Before } \\
\text { Ex- } \\
\text { periment }\end{array}$ & $\begin{array}{l}\text { Sensiti- } \\
\text { zation } \\
10 \text { times }\end{array}$ & $\begin{array}{l}\text { Sensiti- } \\
\text { zation } \\
\text { 20times }\end{array}$ & $\begin{array}{l}\text { After } \\
\text { Sensiti- } \\
\text { zation }\end{array}$ & $\begin{array}{c}\text { After } \\
\text { Re- } \\
\text { injection }\end{array}$ \\
\hline 350 & 75 & & & & 80 \\
\hline & 65 & 76 & 68 & 64 & 6 \\
\hline & 8 & 74 & 85 & & \\
\hline 36 & 83 & 72 & 68 & 8 & 80 \\
\hline & 73 & 73 & & & \\
\hline 37 & 68 & 64 & & 5 & 60 \\
\hline & 75 & 60 & 81 & 8 & 66 \\
\hline 37 & 70 & 71 & 66 & 85 & 75 \\
\hline
\end{tabular}

TARLE 5 Blood

\begin{tabular}{|c|c|c|c|c|c|c|c|c|c|c|c|c|c|c|c|}
\hline \multirow{3}{*}{$\begin{array}{l}2 \\
\vdots \\
0 \\
\text { के } \\
\dot{x} \\
\dot{x}\end{array}$} & \multirow[b]{3}{*}{$\begin{array}{c}\dot{0} \\
Z\end{array}$} & \multirow{3}{*}{ 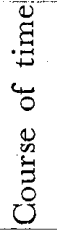 } & \multirow{3}{*}{ 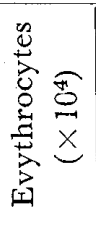 } & \multirow{3}{*}{ 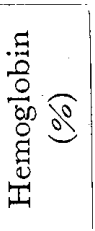 } & \multirow{3}{*}{ 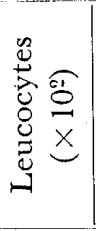 } & \multirow{3}{*}{ 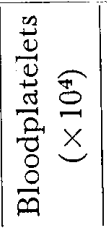 } & \multirow{3}{*}{ 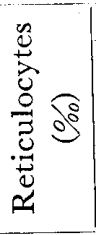 } & \multicolumn{8}{|c|}{ Hemogram } \\
\hline & & & & & & & & \multirow[b]{2}{*}{$\begin{array}{l}\dot{0} \\
\text { कू } \\
\text { คी }\end{array}$} & \multirow[b]{2}{*}{ 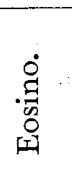 } & \multicolumn{3}{|c|}{ Pseudo.eosino. } & \multirow[b]{2}{*}{ 总 } & \multirow[b]{2}{*}{ 递 } & \multirow[b]{2}{*}{ 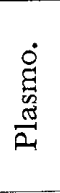 } \\
\hline & & & & & & & & & & 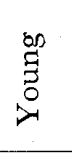 & $\begin{array}{l}\dot{0} \\
\frac{0}{\tilde{\Xi}} \\
\mathbb{1}\end{array}$ & $\underset{\dot{D}}{\dot{\infty}}$ & & & \\
\hline \multirow{3}{*}{$\begin{array}{c}n \\
1 \\
0 \\
0 \\
0 \\
0 \\
0 \\
0\end{array}$} & 350 & $\begin{array}{l}1 \\
2 \\
\end{array}$ & $\begin{array}{l}595 \\
455 \\
\end{array}$ & $\begin{array}{l}65 \\
68 \\
\end{array}$ & $\begin{array}{l}56 \\
88\end{array}$ & $\begin{array}{l}17 \\
14 \\
\end{array}$ & $\begin{array}{r}8 \\
12 \\
\end{array}$ & 1.0 & & & $\begin{array}{l}3.5 \\
4.5 \\
\end{array}$ & $\begin{array}{l}36.5 \\
48.0 \\
\end{array}$ & $\begin{array}{l}59.0 \\
45.0 \\
\end{array}$ & 2.5 & \\
\hline & 367 & $\begin{array}{l}1 \\
2 \\
3 \\
4 \\
5\end{array}$ & $\begin{array}{l}404 \\
579 \\
593 \\
530 \\
552\end{array}$ & $\begin{array}{l}55 \\
60 \\
65 \\
60 \\
65 \\
\end{array}$ & $\begin{array}{l}69 \\
95 \\
83 \\
83 \\
72 \\
\end{array}$ & $\begin{array}{l}27 \\
30 \\
27 \\
48 \\
22\end{array}$ & $\begin{array}{r}10 \\
12 \\
8 \\
18 \\
12\end{array}$ & $\begin{array}{l}2.0 \\
0.5\end{array}$ & 0.5 & $\begin{array}{l}3.0 \\
1.5\end{array}$ & $\begin{array}{r}6.0 \\
15.5 \\
20.5 \\
5.5 \\
4.5\end{array}$ & $\begin{array}{l}20.0 \\
52.0 \\
56.5 \\
50.0 \\
60.5\end{array}$ & $\begin{array}{l}69.0 \\
27.5 \\
20.5 \\
37.5 \\
34.0\end{array}$ & $\begin{array}{l}0.5 \\
6.5 \\
1.0\end{array}$ & 0.5 \\
\hline & 368 & $\begin{array}{l}1 \\
2 \\
3 \\
4 \\
5\end{array}$ & $\begin{array}{l}625 \\
467 \\
324 \\
377 \\
477 \\
\end{array}$ & $\begin{array}{l}80 \\
67 \\
74 \\
65 \\
75 \\
\end{array}$ & $\begin{array}{l}61 \\
98 \\
52 \\
54 \\
78 \\
\end{array}$ & $\begin{array}{l}31 \\
22 \\
26 \\
42 \\
23\end{array}$ & $\begin{array}{r}6 \\
7 \\
9 \\
16 \\
10\end{array}$ & 0.5 & 0.5 & $\begin{array}{l}3.0 \\
2.0\end{array}$ & $\begin{array}{r}14.0 \\
33.5 \\
7.5 \\
2.0 \\
6.0 \\
\end{array}$ & $\begin{array}{l}44.0 \\
47.5 \\
47.5 \\
43.5 \\
51.0\end{array}$ & $\begin{array}{l}40.0 \\
15.5 \\
42.0 \\
52.0 \\
38.5\end{array}$ & $\begin{array}{l}1.5 \\
1.0 \\
2.0 \\
4.5\end{array}$ & \\
\hline \multirow{5}{*}{ 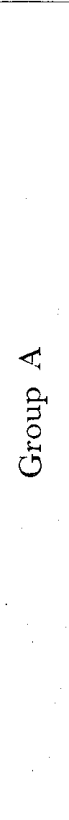 } & 369 & $\begin{array}{l}1 \\
2 \\
3 \\
4 \\
5 \\
\end{array}$ & $\begin{array}{l}458 \\
557 \\
381 \\
547 \\
528\end{array}$ & $\begin{array}{l}62 \\
70 \\
62 \\
65 \\
67\end{array}$ & $\begin{array}{r}79 \\
108 \\
73 \\
106 \\
81\end{array}$ & $\begin{array}{l}19 \\
18 \\
26 \\
38 \\
31\end{array}$ & $\begin{array}{l}12 \\
10 \\
13 \\
18 \\
20\end{array}$ & $\begin{array}{l}0.5 \\
1.0 \\
0.5\end{array}$ & $\begin{array}{l}1.0 \\
0.5\end{array}$ & $\begin{array}{l}1.5 \\
1.5\end{array}$ & $\begin{array}{r}7.0 \\
23.0 \\
6.0 \\
2.5 \\
2.5\end{array}$ & $\begin{array}{l}37.0 \\
49.0 \\
26.5 \\
53.5 \\
36.0\end{array}$ & $\begin{array}{l}55.0 \\
24.0 \\
63.5 \\
42.5 \\
58.5\end{array}$ & $\begin{array}{l}1.0 \\
1.0 \\
0.5 \\
1.5 \\
2.5\end{array}$ & 0.5 \\
\hline & 370 & $\begin{array}{l}1 \\
2 \\
3 \\
4 \\
5\end{array}$ & $\begin{array}{l}569 \\
463 \\
580 \\
516 \\
413\end{array}$ & $\begin{array}{l}74 \\
67 \\
70 \\
68 \\
62 \\
\end{array}$ & $\begin{array}{l}74 \\
66 \\
86 \\
97 \\
79\end{array}$ & $\begin{array}{l}19 \\
16 \\
31 \\
43 \\
14\end{array}$ & $\begin{array}{r}9 \\
16 \\
4 \\
12 \\
18\end{array}$ & 0.5 & 1.0 & $\begin{array}{l}1.0 \\
1.5\end{array}$ & $\begin{array}{r}2.0 \\
14.5 \\
12.5 \\
2.5 \\
3.0\end{array}$ & $\begin{array}{l}31.0 \\
49.0 \\
42.5 \\
33.5 \\
23.0\end{array}$ & $\begin{array}{l}66.0 \\
33.0 \\
41.5 \\
62.0 \\
72.0 \\
\end{array}$ & $\begin{array}{l}1.0 \\
1.0 \\
1.5 \\
2.0 \\
1.5\end{array}$ & 0.5 \\
\hline & 371 & $\begin{array}{l}1 \\
2 \\
3 \\
4 \\
5 \\
\end{array}$ & $\begin{array}{l}508 \\
479 \\
493 \\
386 \\
449\end{array}$ & $\begin{array}{l}73 \\
66 \\
63 \\
58 \\
67\end{array}$ & $\begin{array}{r}82 \\
102 \\
83 \\
120 \\
77\end{array}$ & $\begin{array}{l}25 \\
21 \\
28 \\
28 \\
30\end{array}$ & $\begin{array}{r}6 \\
20 \\
9 \\
8 \\
24\end{array}$ & 1.0 & 0.5 & $\begin{array}{l}3.0 \\
1.5\end{array}$ & $\begin{array}{r}7.0 \\
22.5 \\
2.5 \\
7.5 \\
8.5\end{array}$ & $\begin{array}{l}48.0 \\
49.5 \\
19.0 \\
35.5 \\
61.0\end{array}$ & $\begin{array}{l}41.0 \\
24.0 \\
77.0 \\
53.0 \\
29.0\end{array}$ & $\begin{array}{l}3.0 \\
0.5 \\
1.5 \\
2.5 \\
1.5\end{array}$ & : \\
\hline & 372 & $\begin{array}{l}1 \\
2 \\
3 \\
4 \\
5\end{array}$ & $\begin{array}{l}407 \\
524 \\
656 \\
524 \\
365\end{array}$ & $\begin{array}{l}60 \\
68 \\
70 \\
67 \\
60\end{array}$ & $\begin{array}{r}79 \\
99 \\
93 \\
111 \\
92\end{array}$ & $\begin{array}{l}16 \\
29 \\
37 \\
33 \\
20\end{array}$ & $\begin{array}{l}10 \\
12 \\
16 \\
26 \\
16\end{array}$ & 0.5 & 1.0 & $\begin{array}{l}0.5 \\
1.0 \\
0.5\end{array}$ & $\begin{array}{r}6.0 \\
13.0 \\
13.0 \\
4.0 \\
11.5\end{array}$ & $\begin{array}{l}39.5 \\
44.0 \\
31.0 \\
32.5 \\
52.5\end{array}$ & $\begin{array}{l}47.5 \\
42.0 \\
54.0 \\
61.5 \\
30.5\end{array}$ & $\begin{array}{l}6.0 \\
1.0 \\
2.0 \\
5.0\end{array}$ & \\
\hline & 373 & $\begin{array}{l}1 \\
2 \\
3 \\
4 \\
5\end{array}$ & $\begin{array}{l}643 \\
436 \\
505 \\
557 \\
446\end{array}$ & $\begin{array}{l}70 \\
64 \\
63 \\
65 \\
65\end{array}$ & $\begin{array}{r}70 \\
76 \\
123 \\
81 \\
86\end{array}$ & $\begin{array}{l}23 \\
29 \\
22 \\
36 \\
29\end{array}$ & $\begin{array}{r}12 \\
18 \\
8 \\
18 \\
10\end{array}$ & 0.5 & & 0.5 & $\begin{array}{r}4.0 \\
19.0 \\
11.0 \\
3.5 \\
2.0\end{array}$ & $\begin{array}{l}42.0 \\
38.0 \\
62.5 \\
30.5 \\
51.5\end{array}$ & $\begin{array}{l}53.5 \\
42.5 \\
26.0 \\
65.0 \\
46.0\end{array}$ & $\begin{array}{l}1.0 \\
0.5\end{array}$ & 0.5 \\
\hline & & & & & $\begin{array}{l}\text { t), } 2 . \\
\text { n) } \quad 5 \\
\end{array}$ & & atign & $\mathrm{me}$ & & & on 20 & mes), & & & \\
\hline
\end{tabular}


410

ては，耷静脈末梢部を穿刺して成る可く溶血せざる如く 約 $5 \mathrm{cc}$. の血液を探取使用した。 心筋ホスファティード 反應 ${ }^{107)}$ (C.P.R.) は荒末の方法により實施し，補體測定 には血清中の正常溶血素を除く雼先ず寒冷館和を行う。 即ち血清 $1 \mathrm{cc}$. と山羊赤血球 $1 \mathrm{cc}$. を別々に沈殿管にと り，承中 $\left(0^{\circ} \mathrm{G}\right)$ の中に立てて管の內容が充分冷えた時， 兩者をよく混じ再び氷中に 1 時間放置せる後, 之を內签 の溫度が甚しく上昇世ぬ中に 3 分閒遠心沈段し，上清の 血声を探取す。

1）斯くして得た血清の生理的食監水 10 倍稀釋液を 一列のワッセルマン反應用小試驗管に $1.0,0.9,0.8, \cdots \cdots$ $0.2,0.1$ の如く採取する。

2）各試驗管に生理的食㥼水 $0,0.1,0.2, \cdots \cdots 0.8,0.9$ を 入れ全量を $1 \mathrm{cc}$. とする。

3）豫め山羊赤血球に依り家兔を免疫して得九溶血素 價 1000 倍の溶血素 4 單位を含有する $2.5 \%$ 山羊赤血球浮
第 17 兊 第 9 號

游液を夹々の試驗管に $0.25 \mathrm{cc}$. 混入.

4） $37.0^{\circ} \mathrm{G}$ 水沿上にて 1 時間放置し，溶血を起す血清 の最小量を補體價とする。

血液培養には減菌注射器に依り, 家鬼耳静脈上り除々 に血液 $2 \mathrm{cc}$. を探血，之を $1 \%$ 葡萄糧加ブイヨンに注入 し， $37.0^{\circ} \mathrm{G}$ 餒卵器中にて 48 時間堷盖後山羊血液载萄糖 加寒天平板上に塗擦し，24４8 時間後判定した.

\section{第 2 䈱 臨床的所見}

1）體重：本試驗群並に對照實驗群共に全經猧中大な る消長を見ず，㭊つて榮養不死の影響は除外し得ると考 えられる。(Tab, 2)

2）體㴓：各家東は第 1 回罢丸內注射後，最高 $39.6^{\circ} \mathrm{G}$

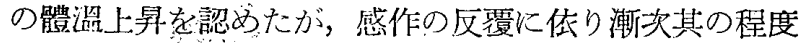
は $38.0^{\circ} \sim 39.0^{\circ} \mathrm{C}$ の閻に減弱し，再注射賞施㘼 $39.5^{\circ} \sim$ $49.0^{\circ} \mathrm{C}$ に急激に上昇した。(Tab. 3)

3）血區：數例に於て再注射後輕度下降の傾向安認め

TARLE 6

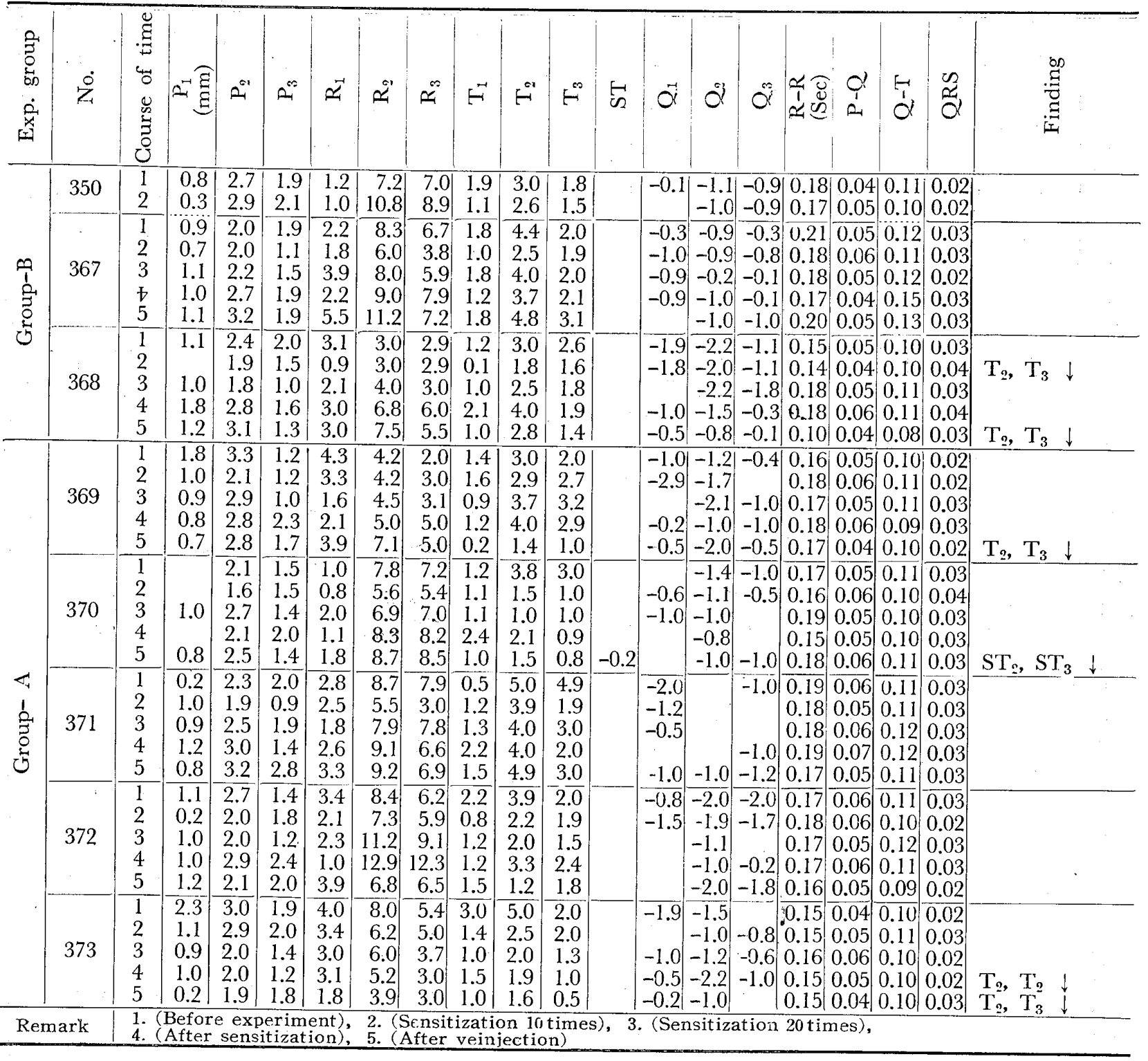


る他，着明なる變化を見ない。(Tab、4)

4）尿所見：檢尿は各家東に就き前後 6 回實施した。 其の成績を見るに，No. 367，371，373 に於て一過性に ウロビリノーゲンが陽性を吾した他，蛋白，糖，沈渣等 には筫常を認めなかつた。

5）血液所見：Table 5 に示す如〈赤血球數，血色素 量，網狀赤血球數には多少の變動を認むるも著明な綡化 無く，白血球數以全例共輕度上昇し，特にNo. 371 に 於て著しく，血小板數は感作の進行と共に僅か上昇し致 死前には元に回復した. 白血球百分率は No. 368,371 に 於て輕度の核左方移動空示したが，其の他は著明な所見 は認められない: (Tab. 5)

6) 心電圖：No. 350 に於て前倦 2 回，他任全經過中 5 回描寫した。

No. 368: 再注射後 $T_{2}, T_{3}$ が下降の傾向を示した.

No. 369: 再注射後 $T_{2}, T_{3}$ が下降した.

No. 370: 再注射後 $\mathrm{ST}_{2}, \mathrm{ST}_{3}, \mathrm{~T}_{2}, \mathrm{~T}_{3}$ が下降の傾向 を示す。

No. 373: 再注射後 $\mathrm{T}_{2}, \mathrm{~T}_{3}$ が下降した.

份心電圖の細部は Table 6 の如くである。

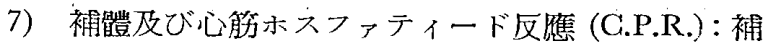
䁗價の減少は No. 350 を例外として，感作前に比較し て再注射後全例に於て認められ，佮感作の初期上り心筋 ホスファティードを使用せるものにては，早期に減少の 傾向あるを示し，心筇ホスファティード反應 (C. P. R.) は第 10 回睪丸內注射の頃より土となり，多少の動播は 認められたが再注射後殆えど全例に於て陽性となつた。 (Tab. 7)

Tabe 7

\begin{tabular}{|c|c|c|c|c|c|c|c|c|c|c|}
\hline \multirow[t]{2}{*}{ No. } & \multicolumn{2}{|c|}{$\begin{array}{l}\text { BeJore } \\
\text { Ex- } \\
\text { periment }\end{array}$} & \multicolumn{2}{|c|}{$\begin{array}{l}\text { Sensiti- } \\
\text { zation } \\
10 \text { times }\end{array}$} & \multicolumn{2}{|c|}{$\begin{array}{l}\text { Sensiti- } \\
\text { zation } \\
20 \text { times }\end{array}$} & \multicolumn{2}{|c|}{$\begin{array}{l}\text { After } \\
\text { Sensiti- } \\
\text { zation }\end{array}$} & \multicolumn{2}{|c|}{$\begin{array}{c}\text { After } \\
\text { Re- } \\
\text { injection }\end{array}$} \\
\hline & $\mathrm{G}$ & G.P. & C. 1 & C.P. & $\mathrm{G}$ & G.P. & C I & G.P. & C & G.P. \\
\hline 350 & 0.06 & - & & & & & & & $0 . \overline{06}$ & - \\
\hline 367 & 0.05 & - & 0.06 & 土 & 0.06 & $t_{i}$ & 0.06 & $t_{1}$ & 0.1 & \pm \\
\hline 368 & 0.05 & - & 0.08 & \pm & 0.08 & - & 0.1 & - & 0.1 & \pm \\
\hline 369 & 0.06 & - & 0.08 & - & 0.08 & - & 0.1 & \pm & 0.1 & +1 \\
\hline 370 & 0.05 & - & 0.1 & - & 0.1 & $+_{1}$ & 0.1 & $t_{1}$ & 0.1 & +1 \\
\hline 371 & 0.04 & - & 0.1 & \pm & 0.08 & \pm & 0.1 & $+_{1}$ & 0.1 & \pm \\
\hline 372 & 0.05 & - & 0.1 & \pm & 0.08 & - & 0.08 & \pm & 0.1 & \pm \\
\hline & 0.06 & - & 0.06 & - & 0.1 & - & 0.1 & \pm & 0.1 & $+_{1}$ \\
\hline & i & & & & & & & & & \\
\hline
\end{tabular}

8）血液培養所見：感作中 2 回，再注射後 2 回棓十 4 回] 實施したが，其の培量成績は全例共陰性である。

9）其の他の郚床所見：感作の初期に於ては，睪丸は 各家鬼共に發赤, 腄張，浫腫等を呈したが壤死は起らず 回を重水るに從い其の程度も輕微となり，再注射時殆ん ぞ全家种共，食思，元氣は衰光(特にNo. 369)たが，强 度のショック㱑狀の發現は見られず，全經過を通じ排便 狀態も良好であつた。

10) 小 括

1. 體重，血涯には著變を認めない。

第 17 卷 第 9 影

2. 體溫は感作の初期及び再注射直後上昇せるも粨次 下降した。

3. 尿は本試驗 2 例, 對照 1 例に於て一過性にウ口ビ リノーゲン陽性を示した他は畋常を認めない。

4. 血液所見にては全例共，全經過を通じ白血球の輕 度の增加，核左方移動を認めた他は著變を見ない。

5. 心電圆は多數例に於て，再注射後 $\mathrm{T}, \mathrm{ST}$ の減高 を示したが對照君では變化は少い。

6. 實驗中殆んど全例に於て補體減少，心筋ホスファ ティード反㷳陽性を示した。

\section{第 3 節 第一次實驗の病理組織學的所見}

本試驗家鬼群には綠色連鎻狀球菌又は心筋ホスファテ イード加綠連菌索以て睪丸內注射し，對照家百群は終始 綠漸菌のみを以て同じく睪丸內に感作，再注射は本試驗 群に心筋ホスファティード加綠連菌を，對照群は綠連菌 のみを静脈內に行い其の心臟，肺藏，脾歳，腎臟，副腎 睪丸を病理組織學的に検查し次の如き所見を得た。

1）心臟の所見

1. 本試驗家鬼群

No. 369: 再注射後 9 日目屠殺.

心內膜に極く輕度の細胞浸潤索認め，心筋間質に特に 右室飞强い著明な形質細胞，單球，組織球，結締織母細 胞等を混ずる小圆形細胞浸潤を見る。此の細胞浸潤は沁 內膜下心外膜にも存在し，心尖部より一般に基底部に多 い. 更に右䇪心外膜下の小動脈周睹に形質細胞を主とす る細胞浸潤めりて，其の間に特に鹽基性の强い巨態細胞 (Fig. 1) を認めた。此の細胞は多核性ではないが，くび れを有する．份小血管周圍の結締織の輕度增殖せる像が 諸々に見られたが，心外膜には著變なく，心筋變性等も 認められない。

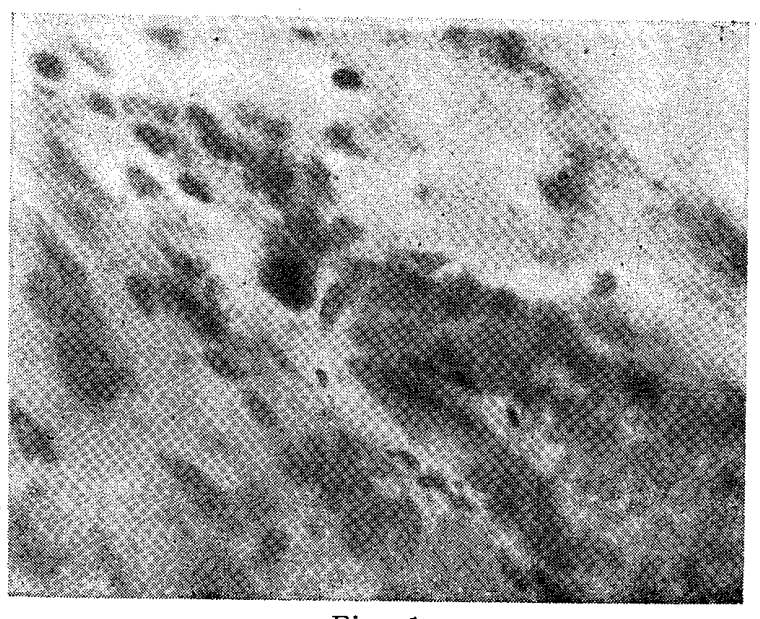

Fig. 1

No. 370 : 再注射後 9 日目屠殺.

心筋間質に著明な潔慢性の細胞浸潤を見る。浸潤は特 に石坴に著明にして，形質細胞を主とし，淋巴球，單球 組織球，結締織母細胞等 (Fig. 2) が混入する. 佾左室の 心尖部に近く小動脈周圍に紡鍎狀の結締織堆殖が岕り， 其の附近に出血䲞の存在が見られた。(Fig. 3) 心內膜, 


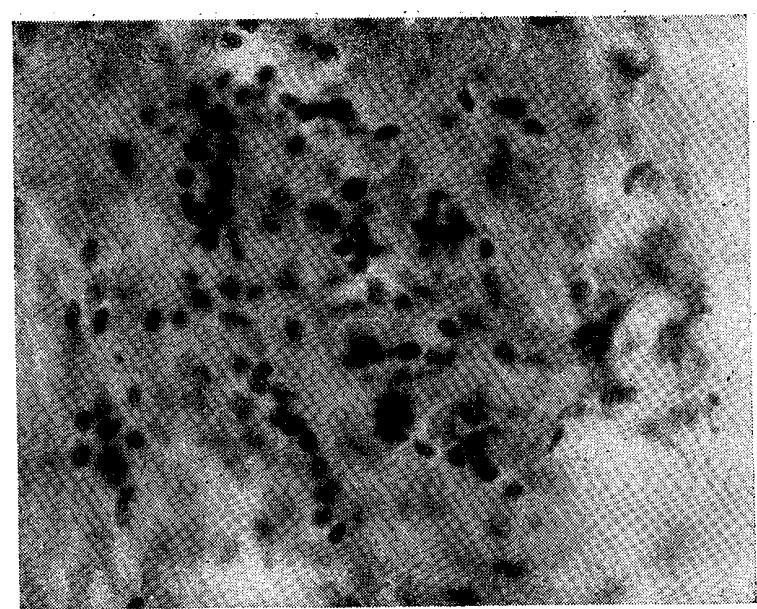

Fig. 2

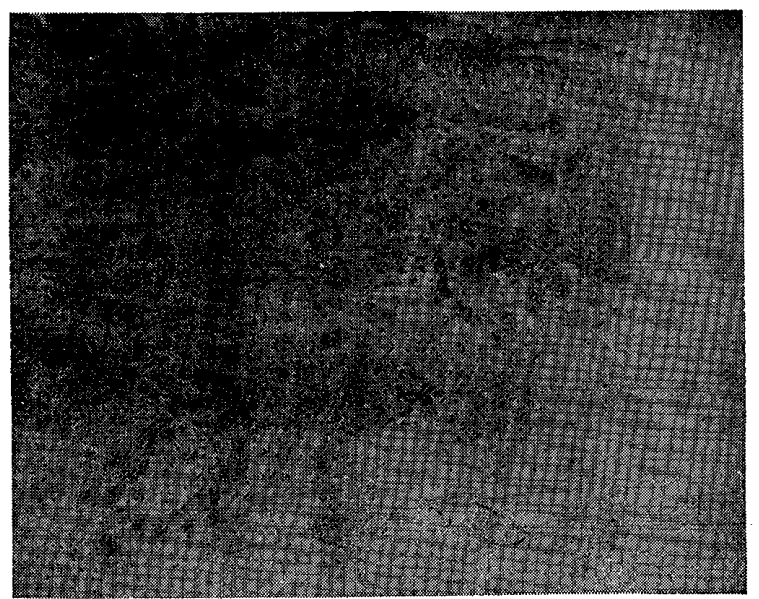

Fig. 3

心外膜，瓣膜，心筋等には著變を認めない。

No. 371：再注射後 3 日目屠殺.

心筋間質の齫基性細胞浸潤は前記 No. 369, 370 と略 同漛であるが，心外膜下に形質細胞，淋巴球，單球等を 以て静成せられる浸潤が多い。之等の細胞浸潤は右室壁 飞强く，小動脈周圍の輕度結締織㙫殖が認められたが， 心內膜，心外膜，瓣膜，心筋等には變化を見ない。

No. 372: 再注射後 3 日目屠殺.

心外膜の被覆細胞文び心內膜內皮細胞の輕度增殖が認 められ，心筋間質の細胞浸潤の狀態，其の棈成細胞の種 類等は No. 369 の夫れと大體一致する. 一般に心筋, 血管には著變なく冠靜脈の整血像は中等度に見られる。

No. 373: 再注射後 9 日目屠殺.

心筋間質細胞浸潤は右室に强く，No. 369 と同樣構成 細胞は形質細胞，淋巴球，單球，組織球等にしてミオチ ーテソを混ずる部分あり，心臟基底部の心內膜に近い小 動脈周圍には，形質細胞を主とし，單球，組織球，淋巴 球，結締織母細胞等より成る小圆形細胞浸潤を認めた。 (Fig. 4) 然し巨態細胞は出現して居ない. 何小動脈の中 膜に於ける繊維樽膨化の像は數個所に認め得られたが， 心內膜，心外膜には特記すべき變化を見ない。

\section{2. 對照家兔群}

No. 350 : 注射後 9 日目屡殺.

心筋間質細胞浸潤は殆んど現出せず，心外膜，心刏膜 血管等は正常に近い.

No. 367 ：再注射後 3 日目屠殺。

心筋間質細胞浸潤は主に右室壁に認められるが，其の 程度は本試驗群に比較し極く輕度である. 唯，心內膜の 內皮細胞瀷殖，心外膜被覆細胞增殖が甚だ輕度に見られ る部分が第る。血管には變化はない。

No. 368 : 再注射後 9 日目屠殺.

冠靜脈の中等度の缽血が認められるが，血管，心队膜 心外膜等には變化舆く; 極く輕微に心外膜下組織の班質 細胞，單球，組織球等の細胞浸潤が見られるのみでま る.

2) 其の他の藏器の所見

1. 肺 臟

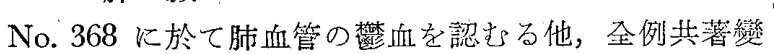
を見ない。

2. 肝 臟

本試驗 (No. 373), 對照 (No. 368) 飞於て細血管に血液 充滿し毛細血管の㕍張が認められる. 其の他著戀なし.

3. 脾”臟

全例共著明なる變化無く, No. 368 に於て極く輕微の

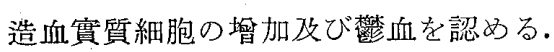

\section{4. 腎 藏}

No. 367 に於て極く輕度の形質細胞を主とする間質性 細胞浸潤，No. 369 にては絲求體に㮐核の堆加せる像を 認むる他，血管，細尿管等に特記すべき著變なし。

\section{5. 副 腎}

本試驗群，對照群を通じ全例共著變を認めない。

6. 睪 丸

本試驗群，對照群共睪丸實質は殆んど破壞せられ，多 核白血球及び其の殘骹を以て充㴖する. (Fig. 5. No. 369)

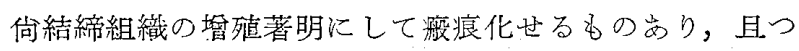
小血管周圍の形質細胞，組織球等より成る周管性鹽基性 咴好性細胞浸潤は殆んど全例に於て證明せられる。

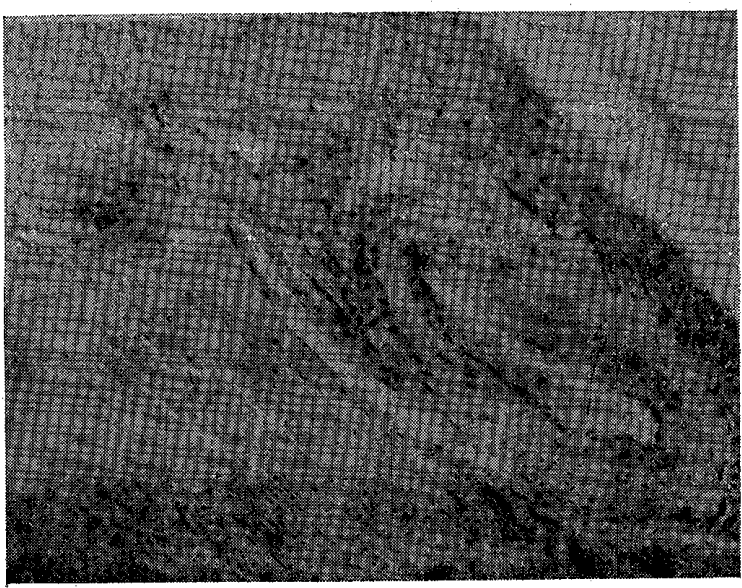

Fig. 4 


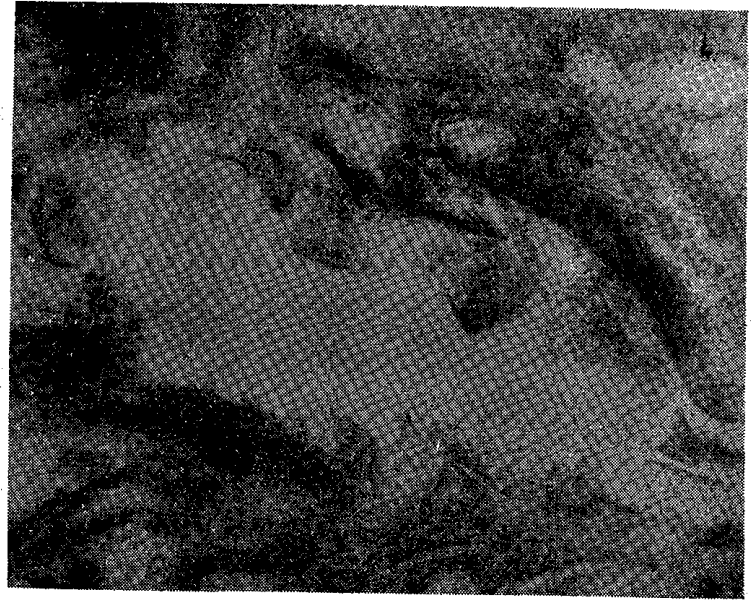

Fig. 5

3) 小括

1. 心筋ホスフォティード加綠色連鎻狀球菌を以てし た本試驗群に於ては，心筋間質に大小種々なる細胞浸潤 を認め，一般に此の浸潤は心尖部よりも基底部に多く， 右室壁に强い，其の構成細胞は形質細胞を主とし，淋区 球，單球，組織球，結綝織度細胞等より成り (Fig. 2),

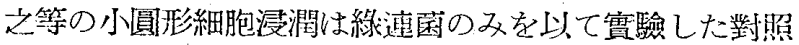
群に比茭して，其の頻度も遥に高度である。
2. 本試驗例の一例に於て，右心空外膜下の小動脈周 園に形質細胞を主とする浸㵎があり，其の間に監基性の 甚だ强い多核性ではないが，くびれを有する豆態細胞を 認めた (Fig. 1).

3. 小血管周圊の結締織の墙殖は本試驗群には甚だ多 く證明せられ；佾其の一例に於ては心尖部に近く小動脈 を中心に結締織渆殖が紡鍾狀に園繞し，血管內腔の狹少 を來たし，其の附近に中等度の出血䇫の存在が認められ た (Fig. 3).

4. 對照家鬼群に於ては本試驗家鬼群に比較して，遥 に程度の劣つた䜿基嘴好性細胞浸潤を認めたが，血管の 變化は見られず，本試驗例の心藏所見は極めて著明にし て全く選擇的である。

5. 睪丸は殆んど全例に於て，膿瘍の形成，結蟐織霄 殖が見られ，小動胍周圍に於ける形質細胞を主とする周 管性血管炎の像俚全例共認められた。

6. 其の他; 肺，肝，脾，副腎等には著變なく，腎の 輕度の間質性小監基性細胞浸潤；絲琭體の核壖加が各 1 例まつたのみである。

文献

第4 章 未尾に一括記載す。

本誌の用紙は日本加工製紙會社井口誠一氏の寄贈によるものです

\section{投 稿 規 定}

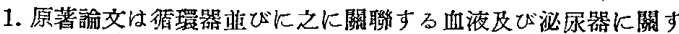
るもので他の藮誌に未盀表のものに限ります。

2. 垃地臨休に關する記事の投稿虏歡迎致しすす。

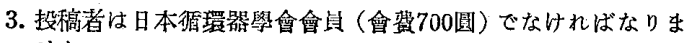
せん。

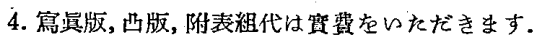

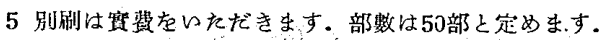

6. 原稿についてはト記の事項长注意しできい.

(イ）外國の人名のトにはアンダーラインを引き, 人名及び地

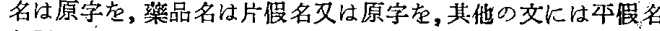
右用ひるてと。

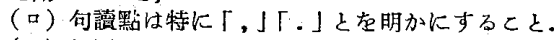

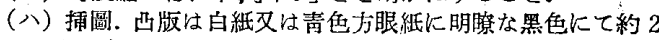
３倍の大きさに描くこと。

（二）寫真は變色のない觧明な燒付にて約 2 3 倍の大いさで あるとと.

（ホ）交嗝の表式は Index Medicus.に従ふこと。

(人) 單位は m. cm. mm. kg. g. mg. 1. cc. 等を用々 るとと.

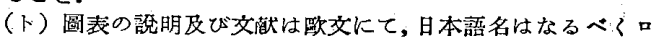
一マ学にて記截のてと.

（チ）原著は殹交抄錄右下記に從ひ各報每に提出してドきい。 a) 題目,著者名,萿者所閩名の臤交譯

b) 和交にして 1500 字內外の䌎交抄錄 (タイプにて)

7. 文の體截武棓は雜誌結一の都合上編集者に於て多少變更させ て戴くことがあります。

\section{[日本䛻環器學誌〕}

\section{第 17 卷・第 9 號}

昭和 28 年 12 月 15 日 印刷

昭和 28 年12月 20 日 發行

誌代年 1200 圓（选料共）

1 册 100 圓 (选料共)

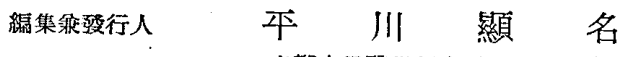
京都大學㗨學部內科學第三讙座

印刷所:河北印刷株式會社 京都市卜京遌店槅門腃时二八

京都大學醫學部內科第三諽座

發行所日本循環器學會 電話 吉田 41111 番

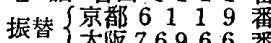

